\title{
Interactive methods of teaching as a way of organizing educational activities in mathematics for students of various profiles at the level of general secondary education
}

\author{
Maria Rassudovskaya ${ }^{1}$, Tatiana Gran ${ }^{1, *}$, Tatiana Sereda ${ }^{1}$, Darya Platonova $^{1}$ \\ ${ }^{1}$ Moscow Region State University, 24, Vera Voloshina str, 141014, Mytishchi, Russia
}

\begin{abstract}
At the present stage of the development of society, there is a need for new personnel ready for self-development and lifelong education. New social requests influenced the development of education, which led to the need to develop new, innovative approaches to the organization of educational activities of students. One of the areas of innovation has been the use of interactive methods in training. The purpose of the study described in the article is to determine the feasibility and advisability of using interactive methods to organize learning activities in mathematics for students of various profiles at the level of general secondary education.
\end{abstract}

\section{Introduction}

The development of modern society leads to the need for processing continuously growing flows of information, which requires the use of such teaching aids that make it possible to transfer a fairly large amount of knowledge in a fairly short period of time and provide a high level of mastery of the studied material by students, followed by fixing it in practice. This problem can be solved using interactive methods in the educational process.

The relevance of the research topic follows from the need to resolve the following contradictions:

- the need to educate a person who meets the requirements of modern society, and difficulties in trying to solve this issue with traditional teaching methods;

- the pedagogical significance of interactive teaching methods and the insufficient development of this problem in the scientific literature.

The purpose of the study is to justify the feasibility of using interactive methods for organizing educational activities in mathematics for students of various profiles, developing methodological recommendations and checking the effectiveness of their use.

One of the ways to organize successful learning activities of students is Scram technology based on the implementation of the Agile methodology. The capabilities of this technology are clearly manifested when organizing with its help students learn various profiles of the topic "Parallel lines and planes in space", which is one of the important and complex topics of the school course in mathematics.

* Corresponding author: tn.gran@mgou.ru 


\section{Materials and Methods}

Interactive learning is understood as learning based on effective feedback, i.e. "Learning immersed in communication." At the same time, interaction and communication does not replace educational activity, but is a condition created by a teacher for a deeper understanding of educational materials, development of problem solving skills, group work skills for making an agreed decision. It is important to note that the interactive in training excludes the predominance of one speaker, one opinion over another. The educational process, organized using interactive forms and teaching methods, allows to involve students in the process of cognition, regardless of their cognitive interests and educational needs [6].

Interactive methods can be defined as ways of targeted interaction between the teacher and students to create optimal conditions for the development of students, where the very logic of the educational process is changed: the formation of new knowledge proceeds through the acquisition of new experience and its theoretical understanding, and not vice versa. In the educational process, the student can be viewed from different perspectives: either as an object of pedagogical influence, and only the teacher is active in this case, or the student is an equal participant in this process. The difference between active teaching methods and interactive ones is that with the interactive teaching method, students take on part of the teacher's functions. With such an organization, not only the teacher attracts students to the learning process, but the students themselves interact with each other and influence each other's motivation.

The specific scientific methodology for using interactive methods consists of two approaches: an activity-based approach to organizing pedagogical interaction and a personal approach to organizing and implementing the pedagogical process. The central concept in the definition of interactive methods is the concept of "interaction". Pedagogical interactions can be considered as deliberate contacts of the teacher with the educated, the purpose of which is to change the behavior and activities of the child. The basis of pedagogical interaction in the learning process is mainly the cooperation of participants in the educational process [8].

During the interactive lesson, stress, muscle and psychological tension are relieved, which contributes to the creation of a positive motivation for learning and, in general, a positive attitude towards school and the student community. A need is being developed for the exchange of information received with cooperation partners, the purpose of which is to expand one's horizons and master new competencies. Collective activity makes it possible to fulfill a variety of social roles, builds teamwork skills, teaches you how to solve conflicts, defend your position, and selects clear language and illustrative examples, builds monologic speaking, dialogue skills and the ability to purposefully and effectively use verbal and non-verbal means communication [5].

Agile technology meets all of the requirements for interactive learning. Agile can be considered as many technologies, for example: Agile Unified Process, Agile Data Method. At its core, Agile is a teaching methodology that provides for the organization of educational activities in which the teaching material is mastered through gradual work with some uncertainty in the information available to students. They perform assigned tasks in relation to self-organized and motivated teams [3]. Such an organization of educational activities complies with the requirements of the Federal State Education Standard.

We describe the principles on which the implementation of the Agile methodology in education is based.

1. The priority in education is to meet the educational needs of students and their families by creating opportunities for continuous productive learning.

2. Changes in the requirements for the educational product obtained in the course of the educational project, possibly even in the late stages of work on it. 
3. Training projects should be carried out as often as possible and last from a couple of weeks to a couple of months, with preference given to shorter intervals.

4. The school and the student's family members must constantly interact to create conditions for productive learning.

5. For the successful implementation of the training project, it is necessary to create favorable conditions, motivate students, trust and support them at all stages.

6. Direct communication is the most effective way to exchange information both with the team itself and within the team.

7. The meaningful development of students learning material is taken as the main indicator of the effectiveness of the educational process.

8. The learning process should be structured so as to remain stable.

9. Constant attention to the technical support and quality of design allows you to increase the efficiency of work on the educational project.

10. It is necessary to create conditions for the self-organization of teams, because it is in such teams that the best ideas and initiatives are born. They are most successful in mastering educational material.

11. The team must constantly look for ways to increase the effectiveness of their work on the project and, accordingly, adjust their activities.

One of the Agile technologies is Scrum technology, then eduScrum is an adaptation of Scrum technology for education. The main idea of training in eduScrum technology is to consciously learn new material from students through their close interaction with other participants in the educational process, as well as to study their own capabilities.

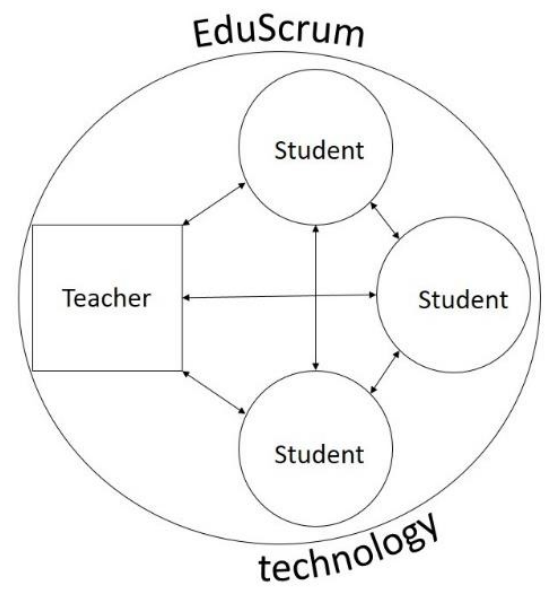

Fig. 1. EduScrum-technology as a means of organizing interactive learning.

In the framework of eduScrum-technology, students are given the freedom to shape the educational process within the designated boundaries and learning objectives. The teacher draws up assignments, directs study groups, consults and supervises them. Such an approach to training allows students to be responsible for their actions, which leads to an increase in the quality of knowledge and to a reduction in the time for mastering educational material. Students are growing confidence in themselves and others, which contributes to their personal development [1].

EduScrum technology involves the formation of teams, the distribution of roles, the sequential passage of the stages of the assignment, the study of theoretical material, following certain rules and algorithms. In order for the educational process to have a constant, regular and predictable nature, it is advisable to divide it into certain stages. Sprint is the connecting link at all stages. Sprint can be considered as part of the learning process, 
allowing you to achieve certain results in a limited period of time. Sprint can be a series of lessons, a project, etc.

Before each lesson, there is a "Stand up" (meeting on the go), which is a short meeting of students to discuss common actions and develop a work plan until the next such meeting. A scram-card and a scram-board allow to organize successful educational activities.

Scrum card contains a complete list of goals and planned results of the development of this educational material, the allocation of educational material, it indicates the possible forms and methods of development of this material. Scrum board is the only visual attribute of the technology. The board allows you to make work on the project more transparent, plan future tasks and put possible limits. The board is drawn into three columns. Each column reflects a specific state of the task: "Scheduled", "In progress", "Done". The board can be considered as a plan with a sufficient level of detail of the task, allowing you to clearly and easily show the degree of completion to all participants in the process.

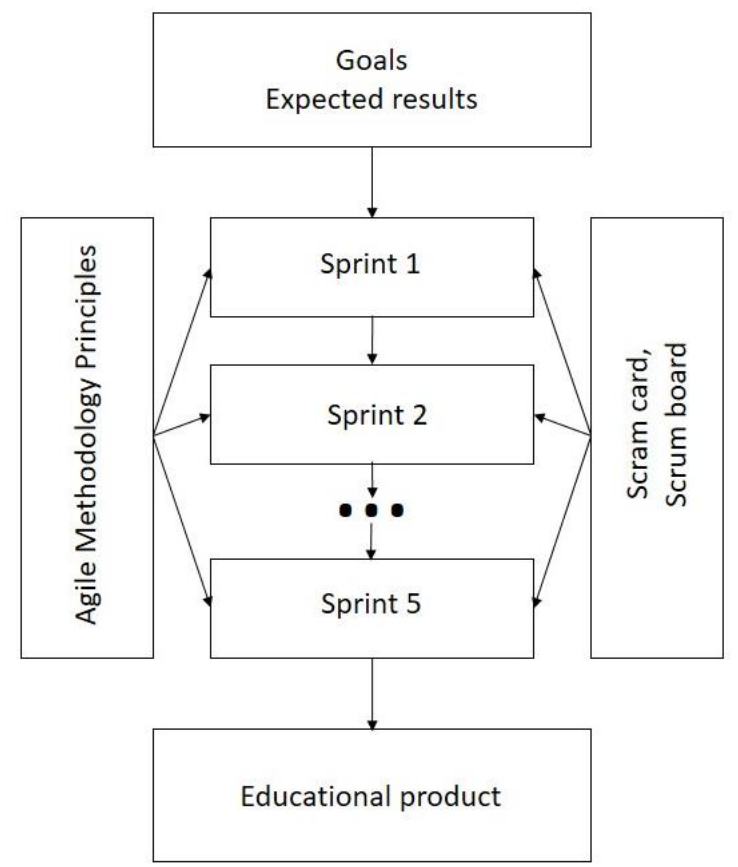

Fig. 2. Organization of educational activities for students using EduScrum technology.

Preparation and conduct of classes within the technology can be divided into 6 stages:

1) Analysis of normative documents;

2) Methodical analysis of a subject;

3) Creating a scrum card for a theme and its applications;

4) Sprint;

5) The developing control;

6) Reflection.

Let 's learn more about some of the steps listed. The purpose of the methodological analysis of the topic is to find techniques, methods and forms of presentation of the selected content of the educational material, which allow to overcome difficulties of its understanding and learning by the students [7].

To create a scrum card, a workbook format can be used where the card itself and its applications are presented, which helps to solve problems such as: 
- more solid assimilation of theoretical principles, as well as the formation of skills to solve not only typical, but also developing, creative tasks;

- mastery of algorithms for solving key problems;

- monitoring the progress of students in mastering a specific educational topic and the formation of their mutual control and self-control skills.

Through the use of a workbook, students will be able to:

- plan your activities correctly in the lesson;

- get acquainted with the content of educational material on the topic;

- to understand what universal educational actions are formed when performing a specific training task and master these actions;

- plan the order of actions and operations for the development of educational material, leading to the planned result of its development;

- to implement interdisciplinary communication in practice;

- ensure coordination of their actions with the actions of other participants in the educational process;

- at each stage of the work, diagnose their achievements of the planned results;

- build your educational process as a project activity.

The developed model of a workbook includes:

- self-assessment and reflection sheet;

- exercises aimed at mastering theoretical educational material;

- a system of tasks contributing to the formation of skills recorded in the planned results of training;

- practical work;

- creative tasks;

- scrum-card of a subject.

At the end of the sprint, there is a lesson in developmental control and reflection. During it, students present their creative work and write a mini-test. Then it takes time to summarize and reflect.

Let's consider how it is possible to organize carrying out sprints on the example of the subject "Parallelism of Straight Lines, Parallelism of a Straight Line and Plane" [4]. Ten hours are allocated for the study of this topic under the program. At the same time, one hour is completely devoted to problem solving and control work. To successfully use Scrumtechnology it is advisable to organize two sprints of five lessons. In each sprint it turned out four lessons of development of new material and formation of skills and one lesson of reflection. Let us describe the first sprint on this topic.

Sprint: "Parallelism of lines, parallelism of a line and a plane."

The plan of the first lesson.

1. Initiation. Entry into the topic.

2. Formation of expectations from the topic.

3. Division into initiative groups.

4. Review lecture.

5. Meeting on the go.

6. Reflection.

The plan of the second lesson.

1. Meeting on the go.

2. Work in initiative groups.

3. The developing control.

4. Reflection.

The plan of the third lesson.

1. Meeting on the go.

2. Work in initiative groups. 
3. The developing control.

4. Reflection.

The plan of the fourth lesson.

1. Meeting on the go.

2. Work in initiative groups.

3. The developing control.

4. Reflection.

The plan of the fifth lesson.

1. Meeting on the go.

2. Demonstration of a creative assignment.

3. Mini test work.

4. Reflection.

For the successful organization of group interaction of students, it is advisable to use cloud services. For example, the Plickers.com service - allows you to conduct an interactive class survey in a short period of time, without using students' mobile devices. To work with this service, you need only a tablet or a teacher's phone in order to read QR codes from students' cards. Cloud technologies offer great opportunities for preparing students for group work, for organizing design and research activities that are used as part of the Scrumbased learning technology [9].

The experimental effectiveness test was carried out at the secondary general education school. The basic idea of the experiment is related to the assumption that the use of interactive teaching methods contributes to the improvement of the efficiency of teaching mathematics of students of different profiles. The purpose of the experiment is to assess the eduScrum of using science-technology to organize educational activities in mathematics of students in classes of different profiles.

On the basis of theoretical analysis of scientific and methodical literature, the following criteria of efficiency of using eduScrum technology were determined:

- quality of knowledge;

- motivation level;

- speed of execution of work (the time taken to complete the task was recorded).

To determine the quality of knowledge of students twice used diagnostic work in mathematics. The change in motivation was recorded using a psychological questionnaire.

\section{Results}

In the process of research, the possibility of using eduScrum-technology in teaching students' mathematics was studied and the feasibility of its use in mathematics lessons was substantiated, based on the psychological and pedagogical characteristics of students. The technology was adapted for use in designing the study of the topic "Parallelism of lines and planes in space" in classes of various profiles. For the organization of educational activities of students developed scrum-cards and methodological applications to them.

During the experiment, the influence of eduScrum-technology on the quality of knowledge, the level of motivation and the speed of work done by students of various profiles was revealed. The results of the study indicate a positive trend (an average increase of $20 \%-35 \%$ ) for all selected research criteria, which proves the validity of the hypothesis.

\section{Discussion}

In the course of a study conducted on the basis of a secondary school, classes were conducted using eduScrum-based teaching technology in classes of mathematical, 
humanitarian and universal profiles. Significant shifts were noted in all observed performance criteria in all classes, which confirms the great educational opportunities of the technologies under consideration. In the course of the study, it was also revealed that eduScrum-technology creates the conditions for the formation and development of universal educational actions in students.

The prospect of further research on this problem can most naturally be connected with the wider use of eduScrum-technology in mathematics lessons, in particular, in the lower grades. It is of interest to study the effectiveness of using this technology to organize the educational activities of university students. [2].

\section{Conclusion}

Interactive methods are aimed at stimulating educational and cognitive motivation, development of independence and activity, education of analytical and critical thinking, formation of communication skills, self-development of students. With the use of interactive teaching methods in mathematics lessons, the level of motivation to learn by subject increases, and the quality of knowledge among students in all training profiles is significantly improved.

By means of pedagogical experiment, the effectiveness of using eduScrum technology as a way of organizing educational activities in mathematics of students of various profiles at the level of secondary general education has been proved. Despite differences in students 'abilities and interests, the use of interactive methods to organize the educational process allows it to be effectively organized for each student.

\section{References}

1. Z. Masood, R. Hoda, K. Blincoe, The Journal of Systems and Software 144 (2018)

2. E.M. Artamonova, Magazine. Pedagogical education and science 5, 17 (2013)

3. R.R. Gatulina, L.F. Kolupaeva, Magazine. St. Petersburg Educational Bulletin 1112(15-16) (2017) https://cyberleninka.ru/article/n/metodologiya-agile-dlyasovremennogo-shkolnogo-obrazovaniya

4. T.N. Gran, Magazine. Pedagogical education and science 6, 53 (2015)

5. N.N. Dvulichanskaya, Magazine. Engineering and computer technology 4 (2011) https://cyberleninka.ru/article/n/interaktivnye-metody-obucheniya-kak-sredstvoformirovaniya-klyuchevyh-kompetentsiy

6. E.V. Korotaeva, Magazine. Pedagogical education in Russia 2 (2012) https://cyberleninka.ru/article/n/interaktivnoe-obuchenie-voprosy-teorii-i-praktikiobucheniya

7. M.A. Lukashenko, T.V. Telegina, Magazine. ANI: Economics and Management 2(27) (2019) https://cyberleninka.ru/article/n/upravlenie-sozdaniem-obrazovatelnyhproduktov-s-pomoschyu-metoda-scrum

8. N.V. Fomicheva, Perm pedagogical magazine 8 (2016) https://cyberleninka.ru/article/n/ispolzovanie-interaktivnyh-form-v-obrazovatelnomprotsesse-starshey-shkoly

9. M.V. Shevchuk, V.G. Shevchenko, Magazine. Computer Science and Education 10(239), 73 (2012) 